\title{
Ischemic Bowel disease
}

\author{
울산의대 서울아산병원 외과학교실 외상 및 중환자외과 \\ 홍 석 경
}

\section{Ischemic Bowel disease}

Suk-Kyung Hong MD, PhD

Division of Trauma and Surgical critical care, Department of Surgery, Ulsan University College of Medicine, Asan Medical Center

허혈성 장질환은 흔하지는 않지만 일단 발현되면 치명적인 질환으로, 장으로 통하는 혈관이 원인이 되는 외부적 원인과 장내 문제에 의한 내부적 원인으로 나눌 수 있다. 원인에 따라, 그리고 발생부위에 따라 예후와 치료 및 치료성적이 다르다. 특히 non-occlusive mesenteric ischemia는 중증 환자에서 볼 수 있는 저혈류성 장허혈로서 조기진단과 적절한 치료를 시행하는 것만이 치료성적을 호전시킬 수 있는 최선의 방법이다.

중심단어 : 허혈성 장질환, 저혈류성, 조기진단, non-occlusive mesenteric ischemia

\section{서 론}

허혈성 장질환(ischemic bowel disease)은 흔히 보는 질환은 아니지만 외과계 중환자실 에서는 드물지 않게 접하게 된다. 초기 증상이 비특이적이라서 복부 불편감에서부터 쇼크까 지 다양하며 진단이 어려운 경우가 많고, 환자

1) Corresponding author

Name : Suk-Kyung Hong

Address : 388-1 Pungnap2-dong, Songpa-Gu, Seoul, Korea

Phone : 82-2-3010-3510

Fax : 82-2-3010-6701

E-mail : skhong94@amc.seoul.kr
가 중증인 경우에는 진단을 놓치거나 뒤늦게 진단되는 경우를 더러 본다. 그러나 수시간 내 에 적절한 치료가 이루어지지 않으면 예후가 매우 불량하여 높은 사망률과 이환율을 보이 며, 30일 생존율을 20 60\%로 보고하고 있다. 특히 위험인자로 잘 알려져 있는 노령인구가 점차 증가하고, 이와 관련된 기저질환이 증가 하여 향후 발생률은 높아질 것으로 예상된다. 따라서 질환에 대한 정확한 이해를 바탕으로 신속하고 적절한 진단과 치료를 하는 것이 매우 중요하다. 


\section{본 론}

병태생리 허혈성 장질환은 장이 정상적인 기능을 하는데 필요한 만큼의 혈류공급이 이뤄지지 않아 발생한다. 장으로 들어가는 혈관이 폐색되면서 생기는 외부적 원인(75\%)과 장내의 문제에 의해 발생하는 내부적 원인(25\%)으로 나뉜다.

외부적 원인으로는 동맥 혹은 정맥이 폐쇅되면서 발생한다. $90 \%$ 에서 동맥에서 기인된 허혈성 장질환이 발생하는데 이는 동맥경화증, 혈전증, 색전증, 박리성 동맥류, 수술, 외상 등이 원인이며, 정맥에 폐색이 생기는 원인으로는 정맥염, 정맥성 혈전증 등이 있다. 장의 융모(villi)에서의 혈류공급은 그림1과 같아서 점막하층에 주로 혈관들이 지나가며, 융모(Villi)의 말단에서는 확산(diffusion)에 의한 단락(shunt)가 이루어진다. 따라서 정맥로가 차단되더라도 융모의 말단에서는 적절한 산소공급이 이뤄지지 못하면서 허혈이 발생할 수 있다. 이를 Counter-current diffusional shunting of villi라고 한다.

장의 내부적 원인으로 인해 허혈성 장질환이 발생하기도 한다. 장으로 유입되는 내장혈관(splanchnic vasculature)에는 이상이 없다 하더라도 장내조직이 살기에 충분한 혈류를 공급받지 못하는 경우가 있다.
1) 기계적으로 장폐색이 발생하여 교액장폐색증(strangulation)이 되거나 장이 과팽창된 경우, 2) Non-occlusive mesenteric ischemia(NOMI)를 유발하는 투석, 심부전, 쇼크, 출혈, 대사성 산증 등의 경우, 3) 염증성 질환으로 복막염, 게실염, 췌장염 등이 동반된 경우, 4) 혈관염 등이 해당된다.

Figure1. Counter-current diffusional shunting of villi

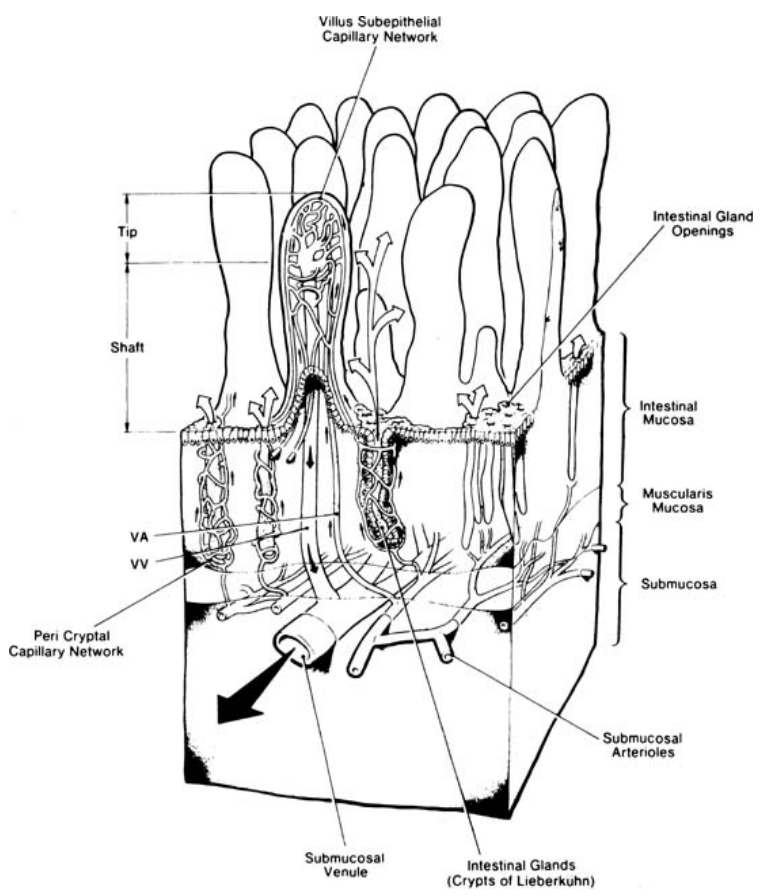

해부학적 위치 : 허혈성 장질환은 장으로의 혈류공급의 해부학적인 구조와 밀접한 관련이 있다.(Figure2) 특히 혈관폐색성 장허혈은 더 욱 관련이 깊다. 상장간막동맥과 하장간막동 맥과의 분수령(Watershed area)은 비자굴곡 
Figure 2. The territory of bowel ischemia according to splanchnic vascular occlusion

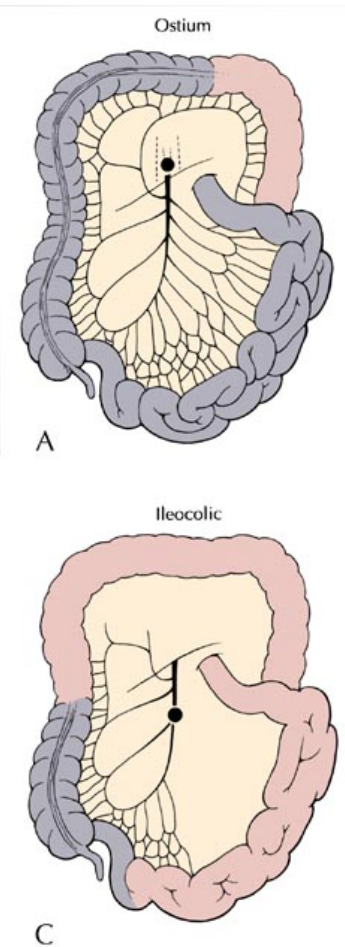

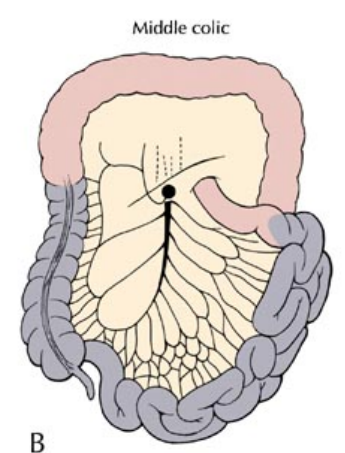

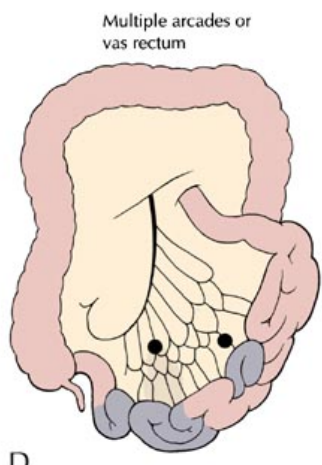

D

흔하지 않다. 혈류공급이 원활하게 일어나기 때문이며 간혹 발생하는 분절성 허혈(Segmental ischemia)은 공장 및 회장에서 발생하며, 허혈 자체에 의해서 보다는 협착성 띠(adhesive band), 염전(volvulus), 내탈장(internal herniation), 신생물(neoplasm), 외상(trauma)에 의해 발생된다.

진단 증상은 복부 불편감, 복통, 혈변, 설사, 구토, 복부팽만, 쇼크 등 매우 다양하다. 특히 소화기계 증상이 발단이 된 쇼크 및 장기부전을 동반한 환자들은 초기 증세에 대한 병력청취를 통해 허혈성 장질환을 의심하여야 한다.

혈액학적 검사는 일반적인 복막염 때 보일 수 있는 백혈구증가증(leukocytosis) 등이

(splenic flexure)이다. 따라서 허혈에 민간한 부위인 반면, 직장은 혈류가 매우 풍부하여 여 간해서는 허혈이 발생하지 않으며 이전에는 직장부위는 허혈이 발생하지 않는다고 까지 하였다. 그러나 근래에 들어오면서, 수술과 관련하여 하장간동맥을 결찰한 경우에는 간혹 직장부위 및 $\mathrm{S}$ 장 결장에서 허혈을 발생하기도 한다. 358 개의 허혈성 장질환을 분석한 연구 에 따르면, 우측결장 27 , 횡행결장 54 , 비장굴 곡(splenic flexure) 84, 하행결장 및 S장 결 장 99 등의 순서를 보였다.

소장에서의 허혈성 장질환은 대장에 비해

나타날 수 있으며, 특히 원인없이 젖산 혈증(lactic acidosis)이나 대사성 산증이 심하거나, 간기능이상을 동반하는 경우, creatinine kinase등이 상승한 경우에는 허혈성 장질환을 의심해 보아야 한다.

복부 X-선 촬영은 비특이적이나 어느 정도 진행된 경우에는 장마비등을 볼 수 있다. 혈관조영술은 허혈성 장질환에서 가장 정확한 검사로 알려져 있으며, 진단과 함께 중재적 시술을 통해 치료를 함께 시도할 수 있다는 장점이 있다. 그러나 침습적인 검사방법이며 $\mathrm{NOMI}$ 의 경우에는 진단적 가치가 떨어진다. 
최근 들어서는 컴퓨터단층검사가 발달되면서 진단적 가치가 많이 높아졌다. 이를 통해 분절성 장벽이 두터워져 있거나, 혈류공급이 이루어지지 않는 것, 점막하층의 부종이 있는 것, 장기종(pneumatosis intestinalis)등은 특징적 소견으로 민감도는 $90 \%$ 를 넘어선다. 그 밖에도 혈관조영을 동반한 $\mathrm{MRI}$ 등의 검사방법이 있다.

그 밖에도 대장내시경을 통해서는 점막의 허혈성 변화를 육안으로 직접 관찰할 수 있다.

치료 복통 및 복막염 증상을 동반하는 경우에는 수술적 치료를 필요로 한다. 통증은 이미 경색(infarction)이 진행된 것을 시사하므로 수술적으로 장을 절제하고 혈관관통술이 가능하다면 함께 하는 것이 좋다. 경색까지 진행되지 않은 경우에는 혈전제거술만을 시행하고 관찰해 보기도 한다. 최근에는 혈관조영술을 통한 중재적방법을 통해 혈전제거술을 하거나 혈전용해제로 녹이는 것을 시도를 하기도 한다.

증상이 모호하면 보존적 치료를 시도할 수 있다. 그러나 2,3 주가 지나도 증상이 지속되거나 환자의 상태가 악화되면 수술적 치료를 고려한다.

허혈성 장질환을 동반한 경우 수술을 결정하는 것은 매우 어려운 일이다. 그러나 여기서 반드시 고려해야 할 것은 허혈의 정도
및 범위와 함께 환자의 중증도이다. 허혈의 정도가 심하고 범위가 넓으면 수술을 일반적으로 고려하지만, 허혈의 정도에 비해 환자의 상태가 중증인 경우에도 수술을 적극적으로 고려하여야 한다. 최근 연구들에도 조기에 수술적 치료를 하는 경우에 비교적 좋은 예후를 보고하고 있다.

NOMI(Non-occlusive mesenteric ischemia) 중증 환자에서 간혹 마주치게 되는 외과적 질환 중 하나는 허혈성 장질환이다. 예후가 안 좋은 것으로 알려져 있으며, 주로 중증 환자에서 발생하므로 수술을 포함하는 치료가 환자에게 큰 부담이 되기 때문에 진단 및 치료를 결정하는 것이 쉽지 않다. NOMI는 'functional mesnteric ischemia' 혹은 'low flow syndrome' 이라고도 일컫는다. 장으로의 혈류가 상대적으로 감소되어 발생하는 것을 일컬으며, 심부전, 저혈압, 저혈량 등에 의해 유발되거나 혹은 혈관수축으로 인해 발생하기도 한다. 소장은 물론 대장까지 침범을 하며, 전체 허혈성 잘질환의 $17 \%$ 까지도 보고하고 있다. 선행질환으로 인해 장허혈이 발생하고, 어느 정도 시간이 지나면 선행질환이 호전되었음에도 불구하고 장허혈은 진행하는 경우가 많다. 특히 동맥질환을 동반하는 투석환자의 경우 투석 시 저혈압과 함께 장허혈을 동반하는 것을 종종 경험한다. 
$\mathrm{NOMI}$ 는 질환이 발생하고 빠른 시간 내에 진단을 하는 것이 예후의 관건이다. $\mathrm{NOMI}$ 의 치료는 다른 허혈성 장질환과는 달리 원인질환을 교정하고, 혈관수축을 효과적으로 해소시키는 것이 관건이다. 이로 인해 일부는 원래로 회복되는 경우도 있으며 이미 어느 정도 진행된 경우에는 허혈성 장질환에 대한 적극적인 치료를 병행해야 한다. 중증 환자에서 갑작스럽게 상태가 악화되고 설명되지 않는 대사성 산증 혹은 젖산혈증이 발생하면 임상적으로 의심하는 것이 가장 중요하다. $\mathrm{NOMI}$ 의 경우에는 전신상태 호전과 함께 장허혈이 호전되는 경우도 종종 본다. 그러나 대부분 NOMI가 발생한 환자들은 고위험군으로 허혈성 장질환이 동반된 경우, 이로 인해 전신적 상태가 악화되는 경우가 대부분이다. 따라서 보존적 치료는 신중하게 선택할 필요가 있으며 환자의 상태가 악화되는 경우에는 주저없이 수술을 시행하여야 한다.

\section{결 론}

허혈성 장질환은 흔히 접하지는 않지만 매우 치명적인 질환 중 하나이다. 원인에 따라 경증에서 중증에까지 다양하게 발현되나, 환자가 중증인 경우에는 수시간내에 적절한 치료를 하지 않으면 사망에까지 이르는 치명적 질환이다.
단일질환으로서 연구가 많지 않아 수술 적응증 및 수술시점이 확립되어 있지 않으며, 개별적인 판단에 따라 치료가 결정되거나, 응급수술로 진행되어 체계적으로 지식과 경험이 축적되어 있지 않은 것이 현실이다. 특히 혈관폐색으로 인한 장허혈은 비교적 치료가 정립되어 있는데 반해, NOMI에 대해서는 아직 치료체계가 정립되어 있지 않다. 외과 중환자 영역에서는 반드시 다루어야 할 질환으로 향후 이에 대한 심도있는 연구가 필요할 것으로 사려된다.

\section{참고문헌}

1. Kazmers A, Zwolak R, Appleman HD, et al. Pharmacologic interventions in acute mesenteric ischemia: improved survival with intravenous glucagon, methylprednisolone, and prostacyclin. J Vasc Surg 1984;1:472-481

2. Wright CD, Kazmers A, Whitehouse WM, Stanley JC. Comparative hemodynamic effects of selective superior mesenteric arterial and peripheral intravenous glucagon infusions. J Surg Res 1985;39:230236

3. Rheudasil JM, Stewart MT, Shellack JV, et al. Surgical treatment of 
chronic mesenteric arterial insufficiency. J Vasc Surg 1988;8:495 -500 .

4. Harward TRS, Brooks DL, Flynn TC, Seeger JM. Multiple organ dysfunction after mesenteric artery revascularization. J Vasc Surg 1993;18:459-469.

5. Bilbao JI, Rodriguez-Cabello J, Longo J, Zornoza G, Paramo J, Lecumberri FJ. Portal thrombosis: Percutaneous transhepatic treatment with urokinase - a case report. Gastrointestinal Radiol 1989;14:326-328.

6. Robin $\mathrm{P}$, Gruel $\mathrm{Y}$, Lang $\mathrm{M}$, et al. Complete thrombolysis of mesenteric vein occlusion with recombinant tissue-type plasminogen activator [letter]. Lancet 1988;1:1391.

7. Picardi E, Rundell WK, Peoples JB. Effects of streptokinase on experimental mesenteric venous thrombosis in a feline model. Curr Surg 1989;46:378-380.

8. Kazmers A. Operative management of acute mesenteric ischemia. Ann Vasc Surg 1998;12:187-197.
9. Kazmers A. Acute embolic and thrombolic mesenteric ischemia. In Current Therapy in Vasacular Surgery. Edited by Ernst CB, Stanley JC. Philadelphia: BC Decker, Inc; 1990:733-740.

10. Kazmers A. Intestinal ischemia from mesenteric venous thrombosis. In Vascular Surgery, 4th edn. Edited by Rutherford R. Philadelphia: WB Saunders; 1995:1288-1300.

11. Mamode N, Pickford I, Leiberman P. Failure to improve outcome in mesenteric ischaemia: seven-year review. Eur J Surg 1999;165:203208.

12. Mansour MA. Management of acute mesenteric ischemia. Arch Surg 1999; 134:328-330.

13. Guntram Lock, juergen Scholmerich. Non-occlusive mesenteric ischemia Hepatro-Gastroenterology 1995;42:234-239

14. Maria Wadman, Ingvar Syk, Solve Elmstah. Survival after operations for ischemic bowel disease 2000;166:872-877 